\title{
Design and Optimization of Substation Grounding Grid for Ensuring the Safety of Personnel and Equipment
}

\author{
Md. Shawkat Hossain ${ }^{1,2, *}$, Raju Ahmed ${ }^{1}$, Shahzad Hossain ${ }^{3}$ \\ ${ }^{1}$ Department of Electrical and Electronic Engineering, Dhaka University of Engineering \& Technology (DUET), Gazipur 1707, \\ Bangladesh. \\ ${ }^{2}$ Department of Electrical, Electronic \& Communication Engineering, Military Institute of Science and Technology (MIST), Mir- \\ pur Cantonment, Dhaka 1216, Bangladesh. \\ ${ }^{3}$ Institute of Nuclear Science and Technology, Bangladesh Atomic Energy Commission, GPO Box No. 3787, Dhaka 1000, Ban- \\ gladesh.
}

\begin{abstract}
How to cite this paper: Md. Shawkat Hossain, Raju Ahmed, Shahzad Hossain. (2021) Design and Optimization of Substation Grounding Grid for Ensuring the Safety of Personnel and Equipment Journal of Electrical Power \& Energy Systems, 5(1), 71-80.

DOI: $10.26855 /$ jepes.2021.08.001

Received: June 26, 2021

Accepted: July 21, 2021

Published: August 18, 2021

*Corresponding author: Md. Shawkat Hossain, Department of Electrical and Electronic Engineering, Dhaka University of Engineering \& Technology (DUET), Gazipur 1707, Bangladesh; Department of Electrical, Electronic \& Communication Engineering, Military Institute of Science and Technology (MIST), Mirpur Cantonment, Dhaka 1216, Bangladesh.

Email: shawkat4405@gmail.com
\end{abstract}

\begin{abstract}
Appropriate design of a substation grounding grid keeping in view of safety of equipment and personnel working area in or walking close to the substation is of great importance. Several steps are involved to design and developed a safe, effective and optimized grounding grid. IEEE Standard 80-2000 explains the terminologies, definitions, formulas and act as an important guide for substation grounding grid design. To date a number of substations grounding grid design intelligent software have already been developed by engineers of many commercial enterprises which takes well care of safety, reliability, continuity of services and optimization of the design. Such a software, e.g., Electrical Transient Analyzer Program (ETAP) has been utilized in this study which has achieved optimization in substation grounding grid design ensuring safety of personnel and equipment. The study utilized the Finite Element Method (FEM) of Ground Grid System (GGS) module of ETAP in combination with Sverak's variable space technique and showcased that $63.88 \%$ copper saving of ground rods could be achieved in comparison with a reference study of substation grounding grid. The method thus has become a very effective tool in substation grounding grid optimization.
\end{abstract}

\section{Keywords}

Ground Potential Rise (GPR), Step Voltage $\left(V_{s}\right)$, Touch Voltage $\left(V_{t}\right)$, Grounding Grid Resistance $\left(\mathrm{R}_{\mathrm{g}}\right)$, Electrical Transient Analyzer Program (ETAP), Finite Element Method (FEM)

\section{Introduction}

Proper design of a substation grounding grid keeping in view safety of substation equipment and personnel working in or walking close to the substation area is of great importance. IEEE Standard 80-2000 delineates terminologies, definitions, formulas and act as an important guide for substation grounding grid design keeping in view safety limits for a $50 \mathrm{~kg} / 70 \mathrm{~kg}$ person [1]. However, this standard is based on approximations and holds good 
for simple grounding grid configuration designed for uniform soil. There are several steps involved to produce a safe, effective and optimized grounding grid design. Manual calculation is a tedious and difficult process as it takes time while precision might be an issue. Hence, computer program is developed now-a-days to greatly improve the process of grounding grid design optimization in terms of time saving, reliability, preciseness and cost.

To make the substation safe for personnel and equipment, fault current must be passed into a low resistivity soil [2]. Resistivity of the soil has a large influence on the optimization result. Selection of a substation site in a low resistivity soil area may not always be possible due to paucity of suitable land. Soil treatment of the substation area may be adopted which may not be economically feasible. The other alternative and which is done in most cases is the burial of an optimized grounding grid under the substation.

A smaller resistivity results in a grounding grid with fewer conductors than a soil with a higher resistivity [3]. For same total length of conductors to be installed in a substation, ground rods are more cost effective than grounding conductors because they penetrate into lower layers of soil in the deep earth which generally have lower resistivity [4]. Ground rods discharge the grid current in the soil at sufficient depth. Thus, they effectively reduce $\mathrm{R}_{\mathrm{g}}$ and GPR which makes the controlling devices more reliable. Also with more number of ground rods, total length of conductors buried in the earth increases thereby decreasing $V_{s}, V_{t}$ and $R_{g}$. In actual practice, ground rods are considered to be an effective means of reducing $R_{g}, V_{s}$ and $V_{t}$ whenever design modifications are necessary [5]. For the same amount of ground rods, there may be two options: (1) Rod length is more with less number of ground rods and (2) Rod length is less with more number of ground rods.

Copper saving is one of the optimization objectives in addition to meeting the safety aspects in substation grounding grid design. Overall cost of a fixed size and shape substation grounding grid depends on material cost, exothermic welding cost, cost of grounding grid conductors and ground rods, excavation/burial/installation cost, labor cost etc. All these costs are related with the amount of copper i.e. grid conductors and ground rods. Nuno et al. [6] has showed that substation designed with more number of ground rods having less length is better because excavation/drilling of ground rods with more length is difficult and costlier.

ETAP is a comprehensive solution for the design, simulation and analysis of generation, transmission and distribution of industrial power systems [7]. ETAP has IEEE method and FEM study model. While IEEE method can be used for some specific shapes, FEM method can be used for any grid shape. The main complications in grounding grid often come after eight to ten years [8]. The under designing is the major issue in problematic grounding grid. Studies show that in general first time structure cost will be more for grounding grid designed by making use of FEM but the grounding grid will be more durable and can withstand the excessive fault currents more efficiently.

For optimization of a 300 feet X 300 feet square grid, FEM of ETAP has been utilized in reference [9] which avoided the tedious and time consuming manual hand calculation involved in the guidelines given in IEEE Standard 80-2000. But it has been found that Sverak's variable spacing technique mentioned in reference [6], which could be an effective tool in optimization of substation grounding grid has not been explored in the study. This led the author to undertake this study on optimization of a substation grounding grid using FEM of ETAP Software in combination with Sverak's variable spacing technique.

Having said all these, the objective of the paper is to optimize substation grounding grid design using FEM of ETAP Software. ETAP provides FEM modeling of ground grid for detailed analysis. Version 16.0.0C of ETAP is used in the study. Input parameters used in the study done by Uma et al. [9] henceforth called the Reference Study has been utilized in this paper.

ETAP software does not have the feature of dealing with high frequency lightning impulse current. Due to this limitation, substation grounding grid design optimization technique only for power frequency eg $50 \mathrm{~Hz}$ ground fault/short circuit environment is discussed in this paper.

\section{Literature Review on Grounding Grid Parameters}

\subsection{Soil Resistivity}

Resistivity of soil depends on type of soil, granularity, density, seasonal factors like temperature, humidity etc. Uniform/homogenous soil variation rarely exists in the geographical area of substation to a considerable depth [11]. More often than not soil resistivity variations are found vertically as well as laterally which also varies with depth and spacing. It is evident that the more complex soil type is simulated, the more time demanding the simulation will be. Fortunately, for most cases, it is sufficient to simulate a two-layer horizontal soil to achieve realistic results [1] 
and [2].

\subsection{Land Area and Grid Configuration}

Area of grounding grid is the single most key factor on which resistance of the grid depends [4]. Thus, when area of grounding grid and soil model is specified, number of grid meshes, side lengths/spacing between conductors, grid conductor diameter, buried depth etc. has negligible effect on reduction in grid resistance. However, for a fixed substation area, it's shape i.e. whether the layout is rectangular, square, T, L and Tri-angular comes into play. T. R. Ayodele et al. [12] showed that L-shape configuration gives the least value of step voltage, GPR and grid resistance. In terms of touch voltage, rectangular configuration is preferred followed by the L-shape.

\subsection{Variable Conductor Spacing and Ground Rod Location}

Grid meshes may be equally or unequally-spaced grid conductors with or without ground rods. For a grounding system consisting only of grid conductors, the current distribution in the soil is fairly uniform. However, a larger portion of the current is discharged into the soil from the outer grid conductors rather than from the conductors at or near the center of the grid [1] and [12]. This non-uniformity of current distribution makes surface potential distribution also non-uniform. Sverak et al. showed that touch voltage is more near the edge of the mesh grid than the centre. An effective way of making the current density more uniform between the inside and periphery conductors is by adopting compression ratio (CR) i.e. to employ a non-uniform conductor spacing, with the conductor spacing larger at the center of the grid and smaller toward the perimeter [1]. Nuno Jorge stated that combining Sverak's variable space technique i.e.by adopting CR in a grid it is possible to achieve a high reduction of the touch voltage, which is the optimization main objective since this parameter is the one that often violates the limits [6]. Reference [6] also proved that it is on the grid's periphery that ground rods are more necessary and produces the best results.

\subsection{Compression Ratio (CR)}

Compression Ratio (CR) is the ratio of mesh spacing between successive pair of meshes from perimeter to center of the grid either in $\mathrm{X}$ - or $\mathrm{Y}$ - direction [12]. The spacing of $\mathrm{n}^{\text {th }}$ conductor counting from center mesh (CM), either in $\mathrm{X}$ - or $\mathrm{Y}$ - direction is given by:

$$
\mathrm{d}_{\mathrm{n}}=\mathrm{d}_{\max } \cdot \mathrm{CR}^{\mathrm{n}}
$$

Where, $d_{n}$ is the spacing of then ${ }^{\text {th }}$ conductor, $d_{\max }$ is maximum spacing of CM and CR is compression ratio. CR is 1 for equally or uniformly spaced grid. For unequally spaced grid, CR is always less than 1 . Higher CR makes the spacing more uniform while lesser CR makes the conductors more crowded at the periphery of the grid. Once the area of grounding grid, number of grid meshes and soil model are specified, every grounding grid has one CR which makes grid resistance, touch voltage and step voltage minimum, is known as Optimal Compression Ratio (OCR) [12].

\subsection{Soil Reflection Factor and OCR}

Abrupt change in resistivity at the boundaries of a two- layer soil is defined by reflection factor, $\mathrm{K}$ and is given by:

$$
\mathrm{K}=\left(\rho_{1-} \rho_{2) /(} \rho_{1+} \rho_{2}\right)
$$

Where, $\rho_{1}$ is the resistivity of first layer up to certain finite depth and $\rho_{2}$ is the resistivity of second layer up to infinite depth.

Unde et al. [12] stated that OCR is very small for positive values of $K\left(\rho_{1}>\rho_{2}\right)$ and it increases as values of K goes from positive to negative. For two layer soil model, OCR is influenced by value of K, first layer depth $\mathrm{H}$ and area of grounding grid.

\section{Factors Affecting Design of Optimized Grounding Grid}

From the study of effects of parameters available in the literature, it became clear that less conductor spacing is desirable for keeping calculated $V_{t}$ less than tolerable $V_{t}$. Basing on reference [6], inference can be made that with the same total amount of grid conductors but less conductor spacing near the edge of the mesh grid (i.e. utilizing OCR) and also placing ground rods at the intersection of the periphery will help achieving optimization respecting 
safety in terms of touch and step potential.

It is worthy to mention that variation of grounding conductor diameter and ground rod diameter does not change $\mathrm{V}_{\mathrm{t}}, \mathrm{V}_{\mathrm{s}}$, GPR and $\mathrm{R}_{\mathrm{g}}$ remarkably. Increased burial depth has the advantage of low $\mathrm{R}_{\mathrm{g}}$ and GPR (GPR being proportional to $R_{g}$ ). Increased rod length also has the advantage of making $V_{t}, R_{g}$ and GPR low. But increased rod length means more material cost. While designing, Sphere of Influence (which is 1.1 times greater than the ground rod length) should be taken into consideration [13] to avoid interference between Sphere of Influence of ground rods and to attain maximum efficiency of the grounding system. However, to make the design more conservative in safety aspect, actual mesh and step voltages must be less than specified percentage of the tolerable value ( $\mathrm{X} \%$ of the corresponding tolerable values), $\mathrm{X}$ being dependent on user requirement [14].

In a substation grounding grid design, with increased burial depth, reduced spacing of grounding conductors and long ground rods, cost of excavation/drilling/installation etc. and labor cost increases. For cost optimization, the thumb rule is that in combination with OCR, ground rods need to be placed mostly at the intersections of the periphery to make the potential distribution more uniform to ensure minimum use of copper while maintaining safety and reliability of the grid.

\section{ETAP Overview}

ETAP is an intelligent graphical enterprise package that runs on Microsoft Windows Operating Systems [15]. Grounding Grid Systems (GGS) module of ETAP enables engineers to quickly and accurately design and analyze ground protection with considerations specified in IEEE Standard 80-2000, IEEE-665-1995 and IEEE-80-1986. The software analyzes the ground grid technically as well as economically. In case of IEEE Method study model, the GGS module performs a cost optimization routine to determine the optimum number of conductors and ground rods needed to limit the step and touch potentials.

The GGS module allow for graphical arrangement of the conductors/ground rods and provide a physical environment to conduct fast, speedy and efficient grounding grid design studies. It is composed of Top View, Soil View and 3-D View. Uniform or two-layer soil view can be used with the FEM study model. The FEM Group Editor provides opportunity to specify every conductor/ground rods length, diameter, material etc individually. ETAP has also user-expandable conductor library. All these facilities allow user to design grid size for any shape and conduct individual case study for achieving optimization.

FEM study model of GGS module allows graphical profiles for the absolute step and touch voltages as well as tables of the voltages at various locations. GGS module of ETAP calculates and compares the tolerable and attainable step and touches potential value and alerts the user if the attainable value exceeds the tolerable value. It generates complete or concise ground grid report in multiple report formats. It is color-coded graphical plot presents step and touch potential profile throughout the grid area. ETAP Interface View with Rod Editor, Interface View with Soil Editor, Grid Analysis Alert View and Touch Potential Profile are shown in Figures 1, 2, 3 \& 4 respectively.

\section{Methodology}

To demonstrate that substation grounding grid design guidelines given in IEEE Standard 80-2000and ETAP simulation results are in close agreement, ETAP software will be validated first by comparing the results given in B. 5 \& B.6 of the standard. Thereafter, ground rods requirement of this study will be compared with that of reference [9] to show the efficacy of FEM of ETAP in combination with Sverak's variable spacing technique as mentioned in the objective of the study. While doing so, same input parameters used in FEM of Reference Study [9] will be utilized in the study except that ground conductor spacing, number, length and location of ground rods will be different from the Reference Study [9] for achieving optimization. To make the design more conservative in safety aspect, tolerable mesh and step voltages will be taken $10 \%$ less than the specified tolerable touch and step voltages.

As the Reference Study [9] has utilized two layer soil having negative value of $\mathrm{K}(\mathrm{K}=-0.889)$, higher $\mathrm{CR}$ values (CR 0.75, 0.85, 0.9 and 0.95) will be utilized in the initial design of the grounding grid. Thereafter, OCR for the grounding grid understudy will be found out.

The first spacing will be calculated by:

$$
\mathrm{d}+\mathrm{d}^{\mathrm{CR}}+\mathrm{d}^{(\mathrm{CR}) 2}+\mathrm{d}^{(\mathrm{CR}) 3}+\ldots \ldots+\mathrm{d}^{(\mathrm{CR}) \mathrm{n}-1}=\mathrm{L}
$$




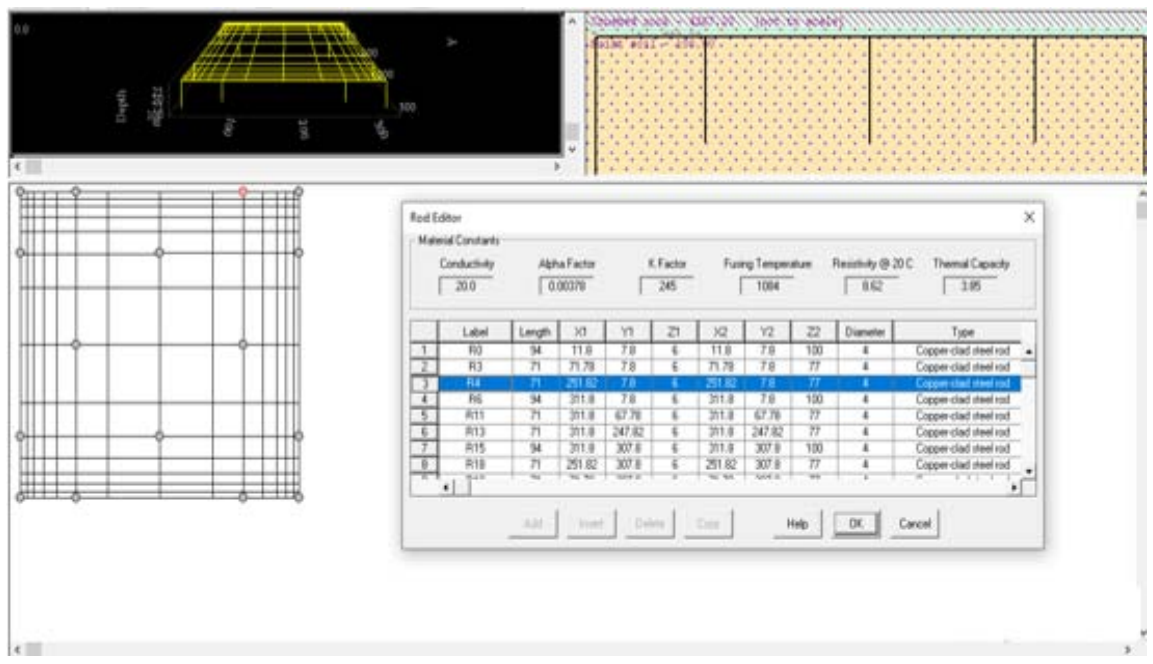

Figure 1. ETAP Interface View with Rod Editor.

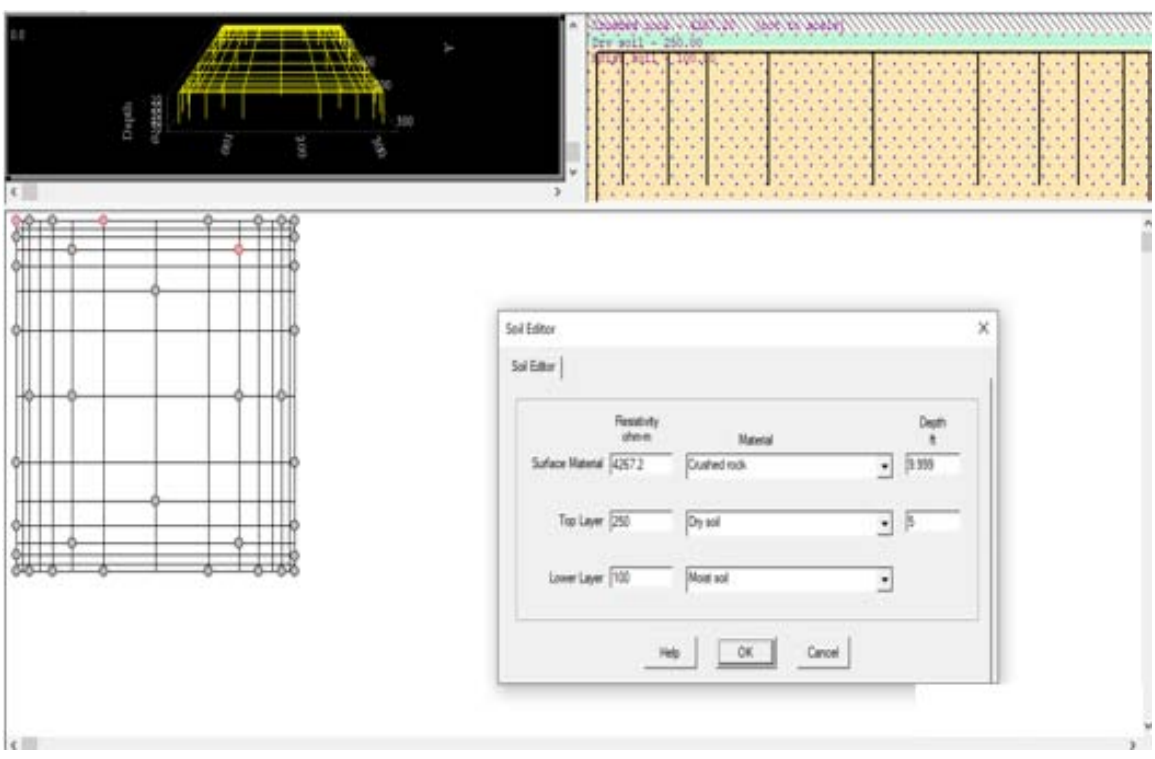

Figure 2. ETAP Interface View with Soil Editor.

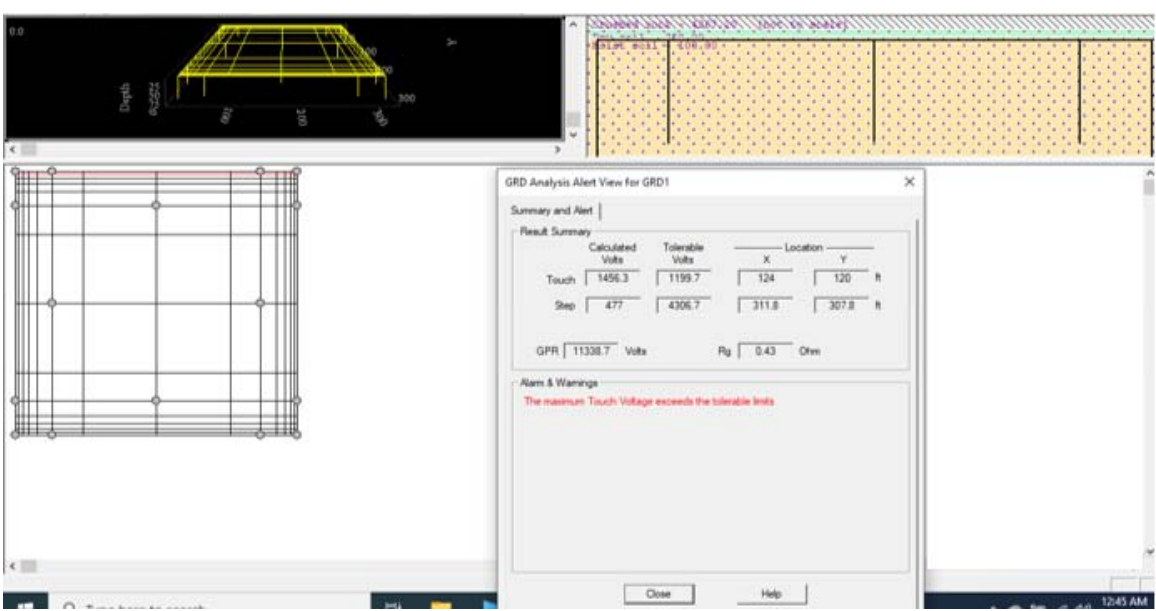

Figure 3. ETAP Grid Analysis Alert View. 


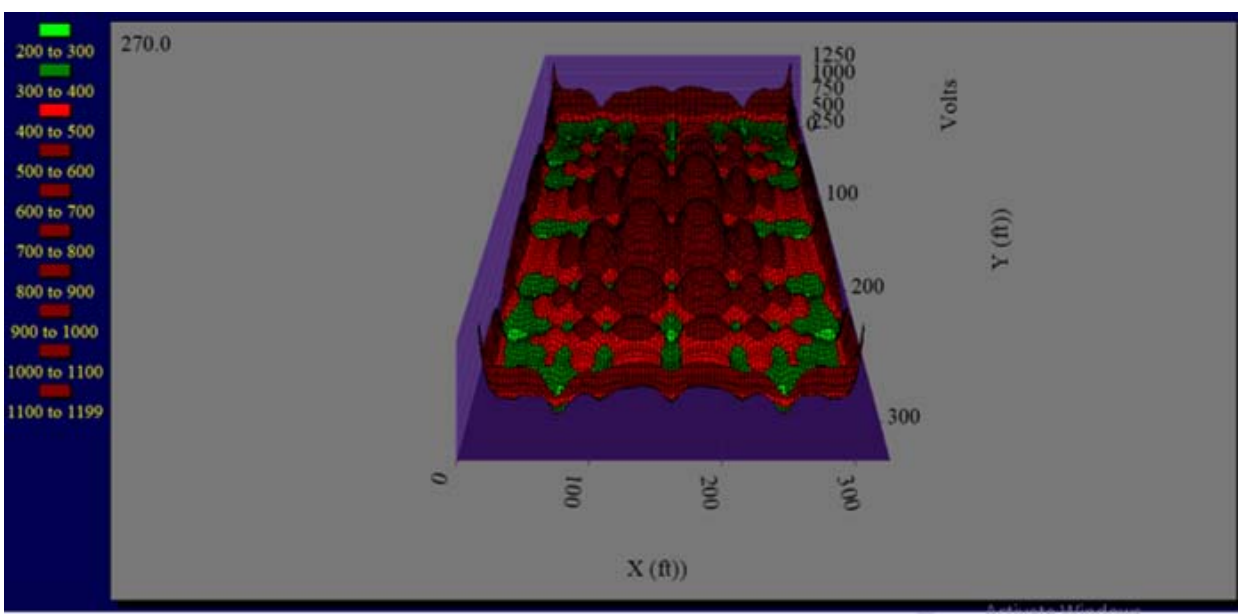

Figure 4. ETAP Touch Potential Profile.

The value of $d$ will be calculated by Newton-Raphson method of solving non-linear equation as following:

$$
\begin{gathered}
f\left(d_{k}\right)=d+d^{C R}+d^{(C R) 2}+d^{(C R) 3}+\ldots \ldots .+d^{(C R) n-1}-L=0 \\
d_{k+1}=d_{k}-f\left(d_{k}\right) / f\left(d_{k}\right)
\end{gathered}
$$

Other spacing was found out from Equation (1). The spacing is given in Table 1.

\begin{tabular}{|c|c|c|c|}
\hline CR & $\begin{array}{c}\text { No of } \\
\text { Conductors }\end{array}$ & Conductor Spacing (Feet) & Remarks \\
\hline 0.95 & 30 & $\begin{array}{l}\text { 11.6, 13.65, 16.3, 19.6, 23.65, 29.1, } \\
\begin{array}{l}36.1,36.1,29.1,23.65,19.6,16.3 \\
13.65,11.6\end{array}\end{array}$ & $\begin{array}{l}\text { From left to Right for conductors in the } \mathrm{X} \text { direction (first value } \\
\text { is for the leftmost mesh, last value is for the rightmost mesh) } \\
\text { From top to bottom for conductors in the Y direction (first value } \\
\text { is for the topmost mesh, last value is for the lowest mesh) }\end{array}$ \\
\hline 0.90 & 30 & $\begin{array}{l}\text { 9.29, 11.3, } 14.04,17.8,23.2,31.15 \\
43.22,43.22,31.15,23.2,17.8,14.04 \\
11.3,9.29\end{array}$ & $\begin{array}{l}\text { From left to Right for conductors in the } \mathrm{X} \text { direction (first value } \\
\text { is for the leftmost mesh, last value is for the rightmost mesh) } \\
\text { From top to bottom for conductors in the Y direction (first value } \\
\text { is for the topmost mesh, last value is for the lowest mesh) }\end{array}$ \\
\hline 0.85 & 30 & $\begin{array}{l}\text { 6.23, } 7.78,10.4,14.42,21.15,33.32 \\
56.7,56.7,33.32,21.15,14.42,10.4 \\
7.78,6.23\end{array}$ & $\begin{array}{l}\text { From left to Right for conductors in the } \mathrm{X} \text { direction (first value } \\
\text { is for the leftmost mesh, last value is for the rightmost mesh) } \\
\text { From top to bottom for conductors in the Y direction (first value } \\
\text { is for the topmost mesh, last value is for the lowest mesh) }\end{array}$ \\
\hline 0.75 & 30 & $\begin{array}{l}\text { 3.25, 4.1, 5.6, 8.4, 14.65, 31.05, 82.95, } \\
82.95,31.05,14.65,8.4,5.6,4.1,3.25\end{array}$ & $\begin{array}{l}\text { From left to Right for conductors in the } \mathrm{X} \text { direction (first value } \\
\text { is for the leftmost mesh, last value is for the rightmost mesh) } \\
\text { From top to bottom for conductors in the Y direction (first value } \\
\text { is for the topmost mesh, last value is for the lowest mesh) }\end{array}$ \\
\hline
\end{tabular}

Table 1. Conductor spacing for CR 0.75, 0.85, 0.9 and 0.95

Objective function of the optimization problem, here cost minimization of the grounding grid under study, are dependent on fitness functions of various particles e.g. number of conductors, conductor dimension, grid depth, number and length of ground rods, etc. [16] and [17]. Optimization of substation grounding grid design being dependent on varied combinations of wide range of geometrical and material parameters can be better dealt by heuristic optimization technique and Artificial Neural Network (ANN) applications [17] and [18]. ETAP software does not have sufficient features of dealing with diverse search space of grounding grid optimization problem. But due to its much faster speed in calculating $\mathrm{R}_{\mathrm{g}}, \mathrm{GPR}, \mathrm{V}_{\mathrm{t}}, \mathrm{V}_{\mathrm{s}}$ etc and with its intelligent FEM Group Editor of GGS module it will be effectively utilized in this study to place required number, size of grounding grid conductor and ground rods at the appropriate location by trial and error method to increase copper saving of ground rods of the substation grounding grid. 
There are many electrical parameters which must be met for evaluating the performance of substation grounding grid. $\mathrm{V}_{\mathrm{t}}$ being the most difficult among these parameters to be met is selected as the constraint function which would ensure the safety requirements of the optimized substation grounding grid. In the Reference Study [9], the author has found out that 9,000 feet copper is required for the grid conductor. Keeping this copper requirement of grid conductor unchanged, only ground rods' copper requirement of the grid will be worked out in this study. Excavation/drilling/installation cost and labor cost etc will not be dealt here. The design requiring less copper for ground rods will be considered as the optimized solution of the grounding grid.

\section{ETAP Simulation}

ETAP simulation parameters used in the study are given in supplementary information file A, simulation result is given in supplementary information file B and simulation report is given in supplementary information file C.

\section{ETAP Simulated Results and Discussion}

Using GGS module of ETAP, OCR for the grounding grid under study has been found as 0.85. ETAP simulation result data is given in Tables 2\&3. Data of Table 2 show that in case of equal spacing in two layer soil, deviation of touch voltage and step voltage between IEEE Standard 80-2000 and ETAP simulation are $2.57 \%$ and $1 \%$ of GPR respectively. These deviations are in close agreement with each other. In case of unequal spacing in uniform soil, deviation of touch voltage between IEEE Standard $80-2000$ and ETAP simulation is $0.71 \%$ of GPR only. Comparison of step voltage could not be done due to non-availability of IEEE Standard 80-2000 value in exhibit 2 of B.6 of the standard. Deviation of grid resistances in these two cases are $9.37 \%$ and $7.33 \%$ respectively which are expected because of the approximate and empirical method of soil model used in IEEE Standard 80-2000.

Data of Table 3 show that Option 2-6 which utilized Sverak's variable spacing technique (i.e. with OCR 0.85) saves $70.35 \%, 63.88 \%, 44.7 \%, 24.94 \%$ and $13.94 \%$ of copper respectively required for ground rods in comparison with Option 1 (Reference Study). Option 4 of the table shows that if touch voltage need to be kept as low as 846.7 Volt (to be comparable with the touch voltage of Reference Study) in that case also it saves $44.7 \%$ of copper required for ground rods. But longest rod`s length in this case is more than 100 feet. In Option 5, where longest rod's length is less than 100 feet it also saves $24.94 \%$ of copper required for ground rods. Considering the difficulty of longer rods in drilling/installation, Option 5 at times may be more suitable than Option 4. Option 6 shows that if all ground rods of same length are utilized, comparatively more copper are required. This is due to the interference effect of Sphere of Influence which decreases efficiency of the ground rods. All these options meet the safety criteria and save considerable percentage of copper required for ground rods. Thus, they are the optimized design of the substation grounding grid and each of the options has its own merits and demerits. In Option 3, even though tolerable mesh voltage value is considered $10 \%$ less than the specified tolerable touch voltage value to make it conservative in terms of safety aspect, it also save $63.88 \%$ copper required for ground rods. It also has the advantage of drilling/installation ground rods of less length, maximum length of ground rod being 71 feet only in comparison with 100 feet ground rod in the Reference Study [9]. Thus Option 3 is the preferred option of the substation grounding grid under study.

Table 2. Validation of ETAP Software with Example B.5 of IEEE Standard 80-2000

\begin{tabular}{|c|c|c|c|c|c|c|c|c|c|c|c|c|}
\hline \multirow{2}{*}{$\begin{array}{l}\text { Type/ } \\
\text { Method }\end{array}$} & \multicolumn{3}{|c|}{ Touch Voltage, $\left(\mathrm{V}_{\mathrm{t}}\right)$} & \multicolumn{3}{|c|}{ Step Voltage, $\left(\mathrm{V}_{\mathrm{s}}\right)$} & \multicolumn{3}{|c|}{ Ground Potential Rise, (GPR) } & \multicolumn{3}{|c|}{ Grid Resistance, $\left(\mathrm{R}_{\mathrm{g}}\right)$} \\
\hline & $\begin{array}{l}\text { IEEE } \\
\text { Std }\end{array}$ & ETAP & $\begin{array}{l}\text { \% } \\
\text { Devia- } \\
\text { tion }\end{array}$ & $\begin{array}{l}\text { IEEE } \\
\text { Std }\end{array}$ & ETAP & $\begin{array}{l}\text { \% } \\
\text { Devia- } \\
\text { tion }\end{array}$ & $\begin{array}{l}\text { IEEE } \\
\text { Std }\end{array}$ & ETAP & $\begin{array}{l}\text { \% Devi- } \\
\text { ation }\end{array}$ & $\begin{array}{l}\text { IEEE } \\
\text { Std }\end{array}$ & ETAP & $\begin{array}{l}\text { \% Devi- } \\
\text { ation }\end{array}$ \\
\hline $\begin{array}{l}\text { Equal } \\
\text { Spacing } \\
\text { (Two } \\
\text { Layer } \\
\text { Soil) } \\
\end{array}$ & $\begin{array}{l}49.66 \\
\% \text { of } \\
\text { GPR }\end{array}$ & $\begin{array}{l}1,123.4 \\
(47.09 \\
\% \text { of } \\
\text { GPR) }\end{array}$ & $\begin{array}{l}2.57 \% \\
\text { of GPR }\end{array}$ & $\begin{array}{l}18.33 \% \\
\text { of GPR }\end{array}$ & $\begin{array}{l}413.2 \\
(17.33 \% \\
\text { of GPR) }\end{array}$ & $\begin{array}{l}1 \% \text { of } \\
\text { GPR }\end{array}$ & - & 2384.6 & - & 1.353 & 1.237 & $9.37 \%$ \\
\hline $\begin{array}{l}\text { Unequal } \\
\text { Spacing } \\
\text { (Uniform } \\
\text { Soil) }\end{array}$ & $\begin{array}{l}17.08 \\
\% \text { of } \\
\text { the } \\
\text { GPR. }\end{array}$ & $\begin{array}{l}473.5 \\
(16.37 \\
\% \quad \text { of } \\
\text { GPR) }\end{array}$ & $\begin{array}{l}0.71 \% \\
\text { of GPR }\end{array}$ & - & $\begin{array}{l}271.8 \\
(9.40 \% \\
\text { of GPR) }\end{array}$ & - & - & 2892.2 & - & 1.61 & 1.5 & $7.33 \%$ \\
\hline
\end{tabular}


Table 3. Comparison of Ground Rod Requirement for 300 Feet X 300 Feet Substation Grounding Grid

\begin{tabular}{|c|c|c|c|c|c|c|c|c|c|c|}
\hline $\begin{array}{l}\text { Method/ } \\
\text { Option }\end{array}$ & $\begin{array}{l}\text { Require- } \\
\text { ment of } \\
\text { Grid Con- } \\
\text { ductor } \\
\text { (Feet) } \\
\end{array}$ & $\begin{array}{l}\text { Number } \\
\text { of } \\
\text { Ground } \\
\text { Rods }\end{array}$ & $\begin{array}{l}\text { Length of } \\
\text { Ground } \\
\text { Rods } \\
\text { (Feet) }\end{array}$ & $\begin{array}{l}\text { Total Re- } \\
\text { quirement } \\
\text { of Ground } \\
\text { Rods } \\
\text { (Feet) } \\
\end{array}$ & $\begin{array}{l}\text { Touch } \\
\text { Voltage, } \\
\left(\mathrm{V}_{\mathrm{t})}\right.\end{array}$ & $\begin{array}{l}\text { Step } \\
\text { Voltage, } \\
\left(\mathrm{V}_{\mathrm{s})}\right.\end{array}$ & $\begin{array}{l}\text { Ground } \\
\text { Potential } \\
\text { Rise, (GPR) }\end{array}$ & $\begin{array}{l}\text { Grid } \\
\text { Resis- } \\
\text { tance, } \\
\left(\mathrm{R}_{\mathrm{g}}\right)\end{array}$ & $\begin{array}{l}\text { Copper } \\
\text { saving of } \\
\text { ground } \\
\text { rods \% }\end{array}$ & Remarks \\
\hline $\begin{array}{l}\text { FEM of } \\
\text { Reference } \\
\text { [9] Study } \\
\text { (Option 1) }\end{array}$ & 9000 & 34 & $\begin{array}{lr}\text { All } & 34 \\
\text { rods } & \text { are } \\
100 & \text { feet } \\
\text { each } & \end{array}$ & 3,400 & 848.1 & 646.9 & 9860.73 & 0.37 & - & $\begin{array}{l}\text { Reference } \\
\text { [9] }\end{array}$ \\
\hline (Option 2) & 9000 & 16 & $\begin{array}{lr}04 & \text { rods } \\
\text { are } & 60 \\
\text { feet } & \text { each, } \\
04 & \text { rods } \\
\text { are } & 70 \\
\text { feet } & \text { each } \\
\text { and } & 08 \\
\text { rods } & \text { are } \\
61 & \text { feet } \\
\text { each } & \\
\end{array}$ & 1,008 & 1199.5 & 463.2 & 11319.9 & 0.429 & $70.35 \%$ & $\begin{array}{l}\text { May also } \\
\text { be adopted }\end{array}$ \\
\hline (Option 3) & & 16 & $\begin{array}{lr}04 & \text { rods } \\
\text { are } & 71 \\
\text { feet } & \text { each, } \\
08 & \text { rods } \\
\text { are } & 43 \\
\text { feet } & \text { each } \\
\text { and } & 26 \\
\text { rods } & \text { are } \\
47 & \text { feet } \\
\text { each } & \\
\end{array}$ & 1,228 & 1078.9 & 422.9 & 10877.1 & 0.412 & $63.88 \%$ & $\begin{array}{l}\text { Conserva- } \\
\text { tive } \\
\text { option in } \\
\text { terms of } \\
\text { safety- } \\
\text { Preferred } \\
\text { Option }\end{array}$ \\
\hline (Option 4) & & 16 & $\begin{array}{lr}04 & \text { rods } \\
\text { are } & 110 \\
\text { feet } & \text { each, } \\
04 & \text { rods } \\
\text { are } & 130 \\
\text { feet } & \text { each } \\
\text { and } & 08 \\
\text { rods } & \text { are } \\
115 & \text { feet } \\
\text { each } & \end{array}$ & 1,880 & 846.7 & 339.7 & 9796.0 & 0.371 & $44.70 \%$ & $\begin{array}{l}\text { Same } \\
\text { touch } \\
\text { voltage as } \\
\text { in Refer- } \\
\text { ence Study } \\
\text { where } \\
\text { longest } \\
\text { rods length is } \\
\text { more than } \\
100 \text { feet }\end{array}$ \\
\hline (Option 5) & & 27 & $\begin{array}{lr}03 & \text { rods } \\
\text { are } & 84 \\
\text { feet } & \text { each, } \\
04 & \text { rods } \\
\text { are } & 100 \\
\text { feet } & \text { each } \\
\text { and } & 20 \\
\text { rods } & \text { are } \\
95 & \text { feet } \\
\text { each } & \end{array}$ & 2,552 & 846.9 & 332.7 & 9862.2 & 0.374 & $24.94 \%$ & $\begin{array}{l}\text { Same } \\
\text { touch } \\
\text { voltage as } \\
\text { in Refer- } \\
\text { ence Study } \\
\text { where } \\
\text { longest } \\
\text { rods le } \\
\text { length is } \\
\text { less than } \\
100 \text { feet }\end{array}$ \\
\hline (Option 6) & & 38 & $\begin{array}{lr}\text { All } & 38 \\
\text { rods } & \text { are } \\
77 & \text { feet } \\
\text { each } & \\
\end{array}$ & 2,926 & 846.0 & 307.3 & 9992.6 & 0.379 & $13.94 \%$ & $\begin{array}{l}\text { All ground } \\
\text { rods } \\
\text { of equal } \\
\text { length }\end{array}$ \\
\hline
\end{tabular}

\section{Conclusions}

The study utilized fast, speedy and efficient ETAP (version 16.0.0C) software for finding out the optimized quantity of ground rods for a substation grounding grid. The ETAP showed that its simulation results are in close agreement with the results obtained in B.5 \& B.6 of IEEE Standard 80-2000. Optimization of substation grounding grid design is dependent on varied combinations of wide range of geometrical and material parameters and can be better dealt by heuristic optimization technique and ANN applications. But ETAP with its faster calculating speed and intelligent FEM Group Editor of GGS module, in combination with Sverak’s variable space technique could save $63.88 \%$ copper required for ground rods in comparison with the reference study while maintaining safety requirement of the substation grounding grid under study. The preferred option has also the advantage of drill- 
ing/installation of ground rods of less length in comparison with the reference study. The method thus has become a very effective tool in substation grounding grid optimization.

\section{List of abbreviations}

IEEE: Institute of Electrical and Electronics Engineers;

ETAP: Electrical Transient Analyzer Program;

GPR: Ground Potential Rise;

GGS: Grounding Grid Systems;

FEM: Finite Element Method;

CR: Compression Ratio;

OCR: Optimal Compression Ratio;

ANN: Artificial Neural Network.

\section{Acknowledgements}

The authors are thankful to Professor Dr. Md. Mamun-Ur Rashid of Bangladesh Army University of Science and Technology for providing with the ETAP Software.

\section{References}

[1] ANSI/IEEE Std. 80-2000, “IEEE Guide for Safety in AC Substation Grounding”, IEEE: Institute of Electrical and Electronic Engineers,Agosto 2000, Inc. New York.

[2] Soni, M., Dr. Abraham George. (2015). “Cost Effective Grounding Grid Design for Substation”, International Journal of Scientific \& Engineering Study, ISSN 2229-5518, Volume 6, Issue 8, August-2015.

[3] Prasad, D. and Sharma, H. C. P. (2012). “Soil Resistivity and Earthing System”. International Journals of Management, IT \& Engineering (IJMIE), ISSN: 2249-0558, Volume 2, Issue 9, 2012.

[4] Dwarka Prasad, Dr. H. C. Sharma. (2015). “Parameters Effecting Substation Grounding Grid Resistance”, ITEE Journal Information Technology \& Electrical Engineering, ISSN: - 2306-708X Volume 4, Issue 1 February 2015.

[5] Anup Kumar and Prasanna D. Bharadwaj. (2015). "Effect of Grid Parameter Variation on the Performance of Grounding System”, International Journal of Electrical, Electronics and Data Communication, ISSN: 2320-2084, Volume-3, Issue-11, November 2015.

[6] Nuno Jorge Lopes Filipe. “Optimization Design of Substation Grounding Grid”, Instituto Superior Técnico, Universidade Técnica de Lisboa.

[7] Prof. Dhruv Balkrushna Luhar. (2015). “Modern Approach to Earthing System Design and it’s Analysis using ETAP Intelligent Software”, International Journal of Advance Research in Engineering, Science \& Technology (IJAREST), ISSN(O): 2393-9877, ISSN(P): 2394-2444, Volume 2, Issue 2, February-2015.

[8] Muhammad Usman Cheema, MBilal Cheema, Adnan Bashir, and M. Usman Aslam. (2015). “A Comparison of Ground Grid Mesh Design and Optimization for 500 KV Substation using IEEE 80-2000and Finite Element Methods”, Electrical and Electronics Engineering: An International Journal (ELELIJ), Volume 4, No. 1, February 2015.

[9] U. U. Uma, L. O. Uzoechi, and B. J. Robert. (2016). “Optimization Design of Ground Grid Mesh of 132/33kv Substation Using ETAP”, Nigerian Journal of Technology (NIJOTECH), Vol. 35, No. 4, October 2016, pp. 926-934.

[10] Prakash K. Makhijani, Chirag J. Soni, Riya B. Agarwal. (2017). "Design of Substation Grounding in A Two Layer Earth Structure (A Case Study Of 132 KV Substation)”, International Journal of Advanced Technology in Engineering and Science, ISSN 2348-7550, Volume Number 5, Issue Number 07, July 2017.

[11] Unde, M. G. and Kushare, B. E. (2015). "Impact of Compression Ratio on Substation Grounding Grid Resistance in Layered Soil”, IJRET: International Journal of Research in Engineering and Technology eISSN: 2319-1163 | pISSN: 2321-7308, Volume: 04 Issue: 01 | Jan-2015.

[12] T. R. Ayodele, A. S. O. Ogunjuyigbe, O. E. Oyewole. (2018). "Comparative Assessment of the Effect of Earthing Grid Configurations on the Earthing System using IEEE and Finite Element Methods”, Engineering Science and Technology, an International Journal, 21(2018), 970-983.

[13] Sajad Samadinasab, Farhad Namdari, Mohammad Bakhshipour. (2014). “A Novel Approach for Earthing System Design Using FiniteElement Method”, Dept. of Electrical Engineering, School of Technology, PDPU, Gandhinagar, Gujarat, India, Article January 2014.

[14] “Optimized Design of Substation Grounding System using Newly Developed IEEE Compliant Software” | ISSN: 2321-9939, 
IJEDRCP1402018 International Journal of Engineering Development and Research | IJEDR(www.ijedr.org) (Two Day National Conference (RTEECE-2014) -17th,18th January 2014) 88.

[15] http://www.etap.com.

[16] V. K. Voon, K. I. Wong, T. C. Tiong, A. Mansour, and K. H. Law. (2019). “Grounding Grid Design in Electrical Power Substation using Optimization Methods, IOP Conference Series: Materials Science and Engineering, 2019.

[17] Benamrane Alik, Madjid Teguar, and Abdelouahab Mekhaldi. (2015). "Minimization of Grounding System Cost using PSO, GAO and HPSGAO Techniques”, IEEE Transactions on Power Delivery, Vol. 30, No. 6, December 2015.

[18] Gouda, O. E., G. M. Amer, and T. M. EL-Saied. (2006). “Optimum Design of Grounding System in Uniform and Non-Uniform Soils Using ANN”, 2006. 